\title{
The Buzz about Anabolic Androgenic Steroids: Electrophysiological Effects in Excitable Tissues
}

\author{
Joseph G. Oberlander ${ }^{a}$ Carlos A.A. Penatti ${ }^{b}$ Donna M. Porter ${ }^{a}$ \\ Leslie P. Henderson ${ }^{a}$ \\ a Department of Physiology and Neurobiology, The Geisel School of Medicine at Dartmouth, Hanover, N.H., USA; \\ ${ }^{\text {b}}$ Departamento de Ciências Médicas, Universidade Nove de Julho - UNINOVE, São Paulo, Brasil
}

\section{Key Words}

Anabolic steroid $\cdot$ Androgen receptor $\cdot \mathrm{GABA}_{\mathrm{A}}$ receptor . Allosteric modulator • Potassium channel • Forebrain •

Aromatase

\begin{abstract}
Anabolic androgenic steroids (AAS) comprise a large and growing class of synthetic androgens used clinically to promote tissue-building in individuals suffering from genetic disorders, injuries, and diseases. Despite these beneficial therapeutic applications, the predominant use of AAS is illicit: these steroids are self-administered to promote athletic performance and body image. Hand in hand with the desired anabolic actions of the AAS are untoward effects on the brain and behavior. While the signaling routes by which the AAS impose both beneficial and harmful actions may be quite diverse, key endpoints are likely to include ligand-gated and voltage-dependent ion channels that govern the activity of electrically excitable tissues. Here, we review the known effects of AAS on molecular targets that play critical roles in controlling electrical activity, with a specific focus on the effects of AAS on neurotransmission mediated by $G A B A_{A}$ receptors in the central nervous system.
\end{abstract}

Copyright ๑ 2012 S. Karger AG, Basel

\section{KARGER}

Fax +4161306 1234

E-Mail karger@karger.ch

www.karger.com
(C) 2012 S. Karger AG, Basel

0028-3835/12/0962-0141\$38.00/0

Accessible online at:

www.karger.com/nen

\section{Anabolic Androgenic Steroids}

Anabolic androgenic steroids (AAS) comprise a large class of synthetic androgens originally designed to treat hypogonadism in men and developmental endocrine disorders $[1,2]$ that are currently also used in the treatment of a wide range of wasting syndromes [3]. While still valuable for the treatment of disease, the nontherapeutic tissue-building benefits of AAS were quickly recognized outside of the clinic. Over the past several decades, the predominant use of AAS has become illicit, with individuals of both sexes administering these drugs to enhance athletic performance or body image [4-7]. Adult men are reported to self-administer AAS at concentrations that reflect $10-100 \times$ therapeutic doses of testosterone prescribed to restore circulating levels of this gonadal androgen in hypogonadal men [6-11]. Girls and women are reported to take AAS at levels equivalent to or even exceeding those administered by men $[5,8,12]$. Thus, the same doses self-administered by men may be expected to yield circulating levels of androgens in women and girls, both synthetic and physiological, which are orders of magnitude higher than their normal physiological levels of androgens [8]. 
Illicit steroid use is typified by elaborate and concurrent combinations of multiple AAS (stacking) with waxing and waning concentrations (pyramiding); regimes that are believed by the users to limit production of catabolic molecules, such as cortisol, and to minimize untoward side effects $[5,13]$. Steroid users also typically coadminister drugs such as $5 \alpha$-reductase inhibitors (finasteride) to minimize untoward effects of steroids, as well as other nonsteroidal compounds such as insulin for energy replacement and triiodothyronine for fat loss $[5,13]$. The number of individual AAS that have been synthesized is large and continues to grow, particularly with the development of designer steroids that may be packaged as unregulated ingredients in nutritional supplements [14].

Despite this diversity, all AAS are synthetic derivatives of testosterone that can be broadly grouped into three classes. The first class of AAS includes compounds derived from esterification of the $17 \beta$-hydroxyl group of testosterone that are commonly injected and are represented by testosterone propionate and testosterone cypionate. Testosterone esters can be hydrolyzed into free testosterone, reduced to $5 \alpha$-dihydrotestosterone, an androgen with higher biological activity at the androgen receptor (AR) than testosterone $[4,15,16]$, or aromatized to estrogens $[4,15]$. Molecules that have been $5 \alpha$-reduced cannot be metabolized into estrogens, but may be metabolized into other androgens, such as $3 \alpha$-androstanediol $[4,15]$. The length of the ester moiety determines both the half-life and the purported desirability of the steroid as an anabolic drug (http://www.steroid.com/ Testosterone-Propionate.php). The second class of AAS includes the 19-nortestosterone derivatives. These compounds have a hydrogen atom substituted for the methyl group of testosterone at C19. The 19-nortestosterone derivatives can also be injected and are typified by nandrolone or its ester, nandrolone decanoate $[1,2]$. Like the testosterone esters in the first class, AAS in this second class can be aromatized to $17 \beta$-estradiol, although not as well as testosterone $[15,17]$, accounting for their popularity among illicit steroid users (http://www.steroid.com/ Deca-Durabolin.php). The third class includes compounds such as methandrostenolone that are alkylated at C17. Because alkylation retards metabolism by the liver, this group of AAS is orally active [1] and is often used for quick gains between cycles (http://www.steroid.com/ Dianabol.php). None of the $17 \alpha$-alkylated steroids is converted into dihydrotestosterone or aromatized to $17 \beta$-estradiol $[15,17,18]$, although they may be converted to other androgenic and estrogenic metabolites $[19,20]$.
Despite the explosion in the number of different AAS that have been synthesized, all AAS are active at the AR and thus have androgenic, as well as anabolic, properties [21-23], although AAS user websites may claim otherwise. In addition to AR-mediated actions, the AAS can also impose important biological actions via estrogen receptor alpha $(\mathrm{ER} \alpha)$ and $\mathrm{ER} \beta$, either directly [24] or following aromatization [25-28], as well as directly via progestin receptors [29]. Beyond their interactions with these classical nuclear hormone signaling pathways, the AAS can elicit rapid effects through interactions with a nonAR/ER microsomal binding site [30], by allosteric regulation of enzymes involved in the biotransformation of steroids $[20,27,31,32]$ and by allosteric modulation of ion channels [33]. Thus, despite recent commentary to the contrary [34], the chemical modifications imposed to alter the properties of the AAS, as well as the concentrations at which they are present in steroid users, have endowed them with abilities to signal via mechanisms that endogenous androgens under normal physiological conditions do not. In order to understand the full repertoire of the consequences of AAS use, one therefore must certainly include, but also move beyond, the realm of classical nuclear AR signaling and consider distinct actions these synthetic steroids have via alternative pathways. The best studied of these nonclassical actions of AAS, especially with respect to their effects in the central nervous system (CNS), is their role as allosteric modulators of the $\mathrm{GABA}_{\mathrm{A}}$ receptor.

\section{GABA $_{A}$ Receptors}

\section{Structure of the $G A B A_{A}$ Receptor}

The $\mathrm{GABA}_{\mathrm{A}}$ receptor is a widely expressed anion-selective ligand-gated channel that subserves an essential role in mediating fast inhibitory transmission in the CNS. The native receptor is a pentameric transmembrane protein for which sixteen different receptor subunit genes $(\alpha 1-\alpha 6, \beta 1-\beta 3, \gamma 1-\gamma 3, \delta, \varepsilon, \pi$, and $\theta)$ have been identified in mammals. Subunit composition determines the basic biophysical properties of the receptor, such as the conductance, mean open time, and the rate of desensitization, as well as the ability of a wide range of substances to allosterically modulate channel function. Expression of different subunit genes, and their incorporation into functional receptors, shows marked region-specific and developmental variation and is governed by changes in the levels of numerous different endogenous regulators, as well as by exogenous drugs [35-37]. The AAS have both acute and 
chronic actions on the $\mathrm{GABA}_{\mathrm{A}}$ receptor. They can impose immediate and significant changes in channel function through direct allosteric modulation of the receptor. They also alter $\mathrm{GABA}_{\mathrm{A}}$ receptor-mediated synaptic transmission through long-term changes in subunit mRNA expression, and resultant changes in channel function, and through affecting the presynaptic release of GABA.

\section{Allosteric Modulation of $G A B A_{A}$ Receptor Function by Acute Actions of AAS}

The 1990s saw the first studies to suggest that the AAS have significant effects on brain function through their actions at the $\mathrm{GABA}_{\mathrm{A}}$ receptor $[38,39]$. Specifically, prolonged exposure to supraphysiological concentrations of testosterone propionate or methandrostenolone was found to left-shift the $\mathrm{EC}_{50}$ for chloride flux induced by GABA in rat cortical synaptosomes, leading the authors to propose a direct action of these AAS on the $\mathrm{GABA}_{\mathrm{A}}$ receptor. While the findings were intriguing, the investigators proposed that the allosteric actions were not due to the AAS themselves, but that the effects arose secondarily, following metabolism of the AAS to neurosteroid derivatives; agents already known to allosterically modulate the $\mathrm{GABA}_{\mathrm{A}}$ receptor [40]. However, the prolonged nature of the treatment, the lack of correlation of behavioral (anxiolytic effects) and serum neurosteroid levels, and the lack of data indicating that methandrostenolone (a 17 $\alpha$-alkylated AAS) could be metabolized to a neurosteroid, begged an alternative explanation. Demonstration that the AAS can directly impose allosteric modulation on the $\mathrm{GABA}_{\mathrm{A}}$ receptor was soon to follow [41, 42]. In these studies, the investigators not only demonstrated enhancement of chloride flux by two $17 \alpha$-alkylated AAS, but also provided important pharmacological data to indicate distinct functional mechanisms and separate binding sites for the AAS and the endogenous neurosteroids. Direct electrophysiological data of acute allosteric modulation of $\mathrm{GABA}_{\mathrm{A}}$ receptor function by $17 \alpha$-alkylated AAS came with the advent of the technique of ultrafast perfusion [43-45]. These studies provided further evidence that the AAS differ from both gonadal steroids and endogenous neurosteroids since $17 \alpha$-methyltestosterone $(17 \alpha-\mathrm{MeT})$, but not testosterone, was shown to be able to elicit allosteric modulation of the $\mathrm{GABA}_{\mathrm{A}}$ receptor; that $17 \alpha-\mathrm{MeT}$ at concentrations as high as $10 \mu \mathrm{M}$ did not directly gate the channel (as can the neurosteroids [46]); and that the mechanisms by which this AAS altered channel gating are distinct from those for the endogenous neurosteroids [37]. Specifically, for receptors that do not contain the $\delta$-subunit, positive neurosteroids show modest dependence on subunit composition [46] and act to slow the rate of recovery from desensitization and prolong deactivation $[47,48]$. For $\delta$-containing receptors, positive neurosteroids elicit dramatic enhancement of currents by stabilizing the open state of the channel [49]. In contrast to the positive neurosteroids, AAS modulation of currents depends upon $\alpha$ - $[43,44]$ as well as $\delta$ - [44] and $\varepsilon$ - [45] subunit composition of the receptor. Specifically, $17 \alpha-M e T$, imposes dramatically different actions at $\alpha_{1}$ - versus $\alpha_{2}$-containing $\left(\alpha_{x} \beta_{3} \gamma_{2}\right)$ receptors and modulates gating through distinct kinetic mechanisms for these two receptor types. This AAS promotes entry into singly liganded open states for $\alpha_{1}$-containing receptors [43], but preferentially enhances the stability of more distal open and desensitized states while destabilizing the proximal desensitized state for $\alpha_{2}$-containing receptors [44]. While positive neurosteroids dramatically enhance currents through $\delta$-containing receptors, AAS are without effect [44]. For $\varepsilon$-containing receptors, $17 \alpha-\mathrm{MeT}$ actually inhibits both the ligand-gated and spontaneously open states of the channel $[45,50]$ through an allosteric block in which this AAS interacts preferentially with and promotes accumulation in a closed state [45]. The disparity in the functional effects of the AAS versus the neurosteroids is consistent with the divergence in the structural signatures of the two classes of molecules. In particular, neither the $3 \alpha$-hydroxyl moiety common to all active neurosteroids nor the $\mathrm{C}_{17}$ or $\mathrm{C}_{20}$ keto group [51] is present in any of the AAS [52].

The mechanism by which $17 \alpha-\mathrm{MeT}$ modulates the receptor is also distinct from that of another well-known class of allosteric modulators, the benzodiazepines, acting at their high-affinity binding site [43, 44]. Moreover, in contrast to the benzodiazepines, modulation elicited by $17 \alpha-\mathrm{MeT}$ is independent of $\gamma$-subunit composition [36]. Taken together, these studies indicate that in addition to their long-term actions mediated by nuclear hormone receptors, the AAS may have significant effects on neural processing via acute alterations in $\mathrm{GABA}_{\mathrm{A}}$ receptor function that have similarities to, but are nonetheless distinct from, those of other important psychoactive modulators of this channel.

Changes in $G A B A_{A}$ Receptor-Mediated Transmission

Elicited by Chronic Exposure to AAS

Neural Regions That Regulate Sexual Behaviors and

Reproduction

Neurotransmission mediated by $\mathrm{GABA}_{\mathrm{A}}$ receptors regulates pubertal onset, reproductive function, and sexual behaviors [52-56]. One of the seminal outcomes of 
chronic use of high concentrations of AAS is disruption of these functions $[52,53]$. In human subjects, AAS use is not limited to adults, and $2-5 \%$ of high school students are estimated to illicitly administer AAS $[57,58]$. Early AAS use in teenagers $[7,57]$ engenders heightened concern since risks associated with its use may be greater in adolescents than in adults, given the greater hormone sensitivity of the brain during this period $[59,60]$.

Chronic exposure during adolescence to the AAS $17 \alpha-$ $\mathrm{MeT}$ disrupts reproductive function in both male and female mice $[52,53]$. In both sexes, interference with the peripheral reproductive state was found to be accompanied by significant decreases in the frequency of action potentials in gonadotropin-releasing hormone $(\mathrm{GnRH})$ neurons $[61,62]$, neurons that mediate the final control over the hypothalamic/pituitary/gonadal axis [56]. AAS treatment had no direct effect on the expression of $\mathrm{GABA}_{\mathrm{A}}$ receptor subunit mRNAs in identified GnRH neurons, nor did treatment alter the amplitude or decay kinetics of $\mathrm{GABA}_{\mathrm{A}}$ receptor-mediated spontaneous postsynaptic currents (sPSCs), miniature sPSCs, or tonic currents in these cells. These data indicate that AAS treatment was without an appreciable effect on the complement or function of postsynaptic $\mathrm{GABA}_{\mathrm{A}}$ receptors expressed in GnRH neurons [61, 62]. However, treatment did result in a significant increase in the frequency of sPSCs onto GnRH neurons in both sexes, consistent with a significant effect of AAS exposure on neurons that provide afferent GABAergic innervation to the $\mathrm{GnRH}$ cells. In male mice, this increase in sPSC frequency could be attributed to augmented activity of presynaptic GABAergic neurons within the medial preoptic area (mPOA) [61]. While studies in female mice also demonstrated significant effects of chronic exposure to $17 \alpha-\mathrm{MeT}$ on the activity of neurons within the mPOA, the actions were not correlated with concomitant changes in GnRH neuronal activity. Rather, data from this study suggested that AAS impart their actions on GnRH neuronal function in females by altering the activity of afferent kisspeptin-expressing neurons in the anteroventral periventricular nucleus (AVPV) [62]. The identification of upstream neurons in the mPOA and the AVPV as the targets of long-term AAS effects is consistent with the marked level of expression of both $A R$ and $E R \alpha / \beta$ in these afferent regions [63-65], and the dearth of $\mathrm{AR}$ and $\mathrm{ER} \alpha$ in the GnRH neurons themselves [66-68] (fig. 1a, b).

While studies examining the effects of the AAS $17 \alpha-$ MeT have provided important mechanistic information about the actions of the AAS, exposure to only one single compound does not reflect typical patterns of steroid us- age in human subjects [5]. Studies of adult male and female mice treated with a mixture of commonly abused AAS (testosterone cypionate, methandrostenolone, and nandrolone decanoate), which are more likely to reflect a regime administered by people, have also revealed significant effects of chronic AAS treatment on neurons within the mPOA. Moreover, these studies demonstrated that AR signaling is critical in mediating some but not all of these effects, and, as noted above, that sex-specific differences were evident in the actions of this mixture of AAS on specific neuronal populations. In adult male mice, chronic treatment with this AAS mixture promoted enhanced action potential firing of neurons within the mPOA [27], while this same treatment led to significantly lower levels of activity in mPOA neurons of female mice [69]. In both sexes, prolonged exposure to this mixture led to significant increases in the expression of the $\alpha_{5}$-subunit mRNA $[27,69]$ and in changes in $\mathrm{GABA}_{\mathrm{A}}$ receptor-mediated synaptic currents that were consistent with augmented expression of $\alpha_{5}$-containing receptors [69]. Loss of AR-mediated signaling, either pharmacologically by concomitant treatment with the AR antagonist flutamide [69] or genetically by germ line loss of functional AR in the testicular feminization ( $\mathrm{Tfm}$ ) mutant mouse [27], abrogated the AAS-induced effects on action potential firing and $\alpha_{5}$-expression.

Interestingly, significant actions of chronic AAS were nonetheless evident in the Tfm mice, indicating that physiological actions of these synthetic steroids can be mediated by AR-independent means [27]. Specifically, AAS treatment of $T f m$ mice elicited a significant decrease in the frequency and amplitude of $\mathrm{GABA}_{\mathrm{A}}$ receptor-mediated spontaneous inhibitory postsynaptic currents and a significant decrease in levels of the mRNA encoding the 65 $\mathrm{kDa}$ isoform of the GABA synthesizing enzyme glutamate decarboxylase in the mPOA. Experiments in this study went on to show that the electrophysiological effects on $\mathrm{GABA}_{\mathrm{A}}$ receptor-mediated currents could be attributed to AAS-dependent inhibition of aromatase activity and thus antagonism of endogenous ER-mediated actions that normally augment GABAergic tone in the mPOA [70]. These data in the mammalian CNS [27] are consistent with previous studies in nonneuronal cell lines [20,31] and nonmammalian vertebrates [32] demonstrating the ability of the AAS to inhibit the activity of aromatase.

Neural Regions That Regulate Anxiety, Fear, and Stress

In addition to effects on reproduction, chronic AAS use in people is associated with a plethora of effects on 
affect, including depression, mania, hypomania, somatization, increased anxiety, irritability, extreme mood swings, abnormal levels of aggression, body dysmorphia, and paranoia $[6,10,71-74]$. Recent studies in mice provide information on fundamental mechanisms that may underlie some of these actions in demonstrating that chronic AAS treatment alters GABAergic transmission in neural circuits that are critical for the expression of fear, anxiety, and depression. Specifically, treatment of female mice during adolescence with a mixture of AAS (methandrostenolone, nandrolone decanoate, and testosterone cypionate) significantly augmented firing of neurons from the central amygdala $(\mathrm{CeA})$ that project to the bed nucleus of the stria terminalis $(\mathrm{BnST})$ and $\mathrm{GABA}_{\mathrm{A}}$ receptor-mediated inhibition in these target BnST neurons [75]. This projection provides an essential limb of the neural circuitry within the extended amygdala that is crucial for the generation of generalized anxiety [76]. Consistent with altered transmission in this pathway, AAS treatment increased anxiety-like behavior as determined by the acoustic startle response and the elevated plus maze $[75,77]$. As with the effects of $17 \alpha-\mathrm{MeT}$ on GABAergic afferents to GnRH neurons [61, 62], the observed effects of chronic exposure of this AAS mixture at the CeA to BnST synapse were presynaptic: the treatment promoted an increase in $\mathrm{GABA}_{\mathrm{A}}$ receptor-mediated sIPSC frequency, but no change in the amplitude or kinetics of either spontaneous inhibitory postsynaptic currents or mIPSCs in the BnST neurons [75]. The ability of the AAS to elicit both the changes in anxiety and the aug-

Fig. 1. Electrophysiological actions of the AAS on GABAergic transmission in regions of the mammalian forebrain. a Coronal section of a rat brain demonstrating labeling associated with an antisense mRNA to the $\gamma_{1}$-subunit of the $\mathrm{GABA}_{\mathrm{A}}$ receptor. The $\gamma_{1}$ is preferentially expressed in the mPOA and the BnST, and thus provides demarcation of these two regions. b The AAS $17 \alpha-\mathrm{MeT}$, acting through the $A R$, promotes an increase in the frequency of $\mathrm{GABA}_{\mathrm{A}}$ receptor-mediated sPSCs and decreased action potential (AP) firing in GnRH neurons of both the male and female mouse. In males, the AAS effects on GnRH neurons can be attributed to an increase in firing in neighboring GABAergic (neurons in the $\mathrm{mPOA}$ ) [61]. In females, the decrease in firing of $\mathrm{GnRH}$ neurons does not correlate with changes in firing in $\mathrm{mPOA}$ neurons, but does correlate with AAS-induced changes in the firing and expression of kisspeptin in neighboring neurons in the AVPV [62]. c In the BnST, treatment of female mice with a mixture of AAS results in an increase in firing of $\mathrm{CeA}$ neurons and a concomitant increase in the frequency of $\mathrm{GABA}_{\mathrm{A}}$ receptor-mediated spontaneous inhibitory postsynaptic potentials (sIPSCs) and diminished firing in postsynaptic BnST neurons. The actions of the AAS require CRF signaling through the CRF type 1 receptor $[75,77]$.
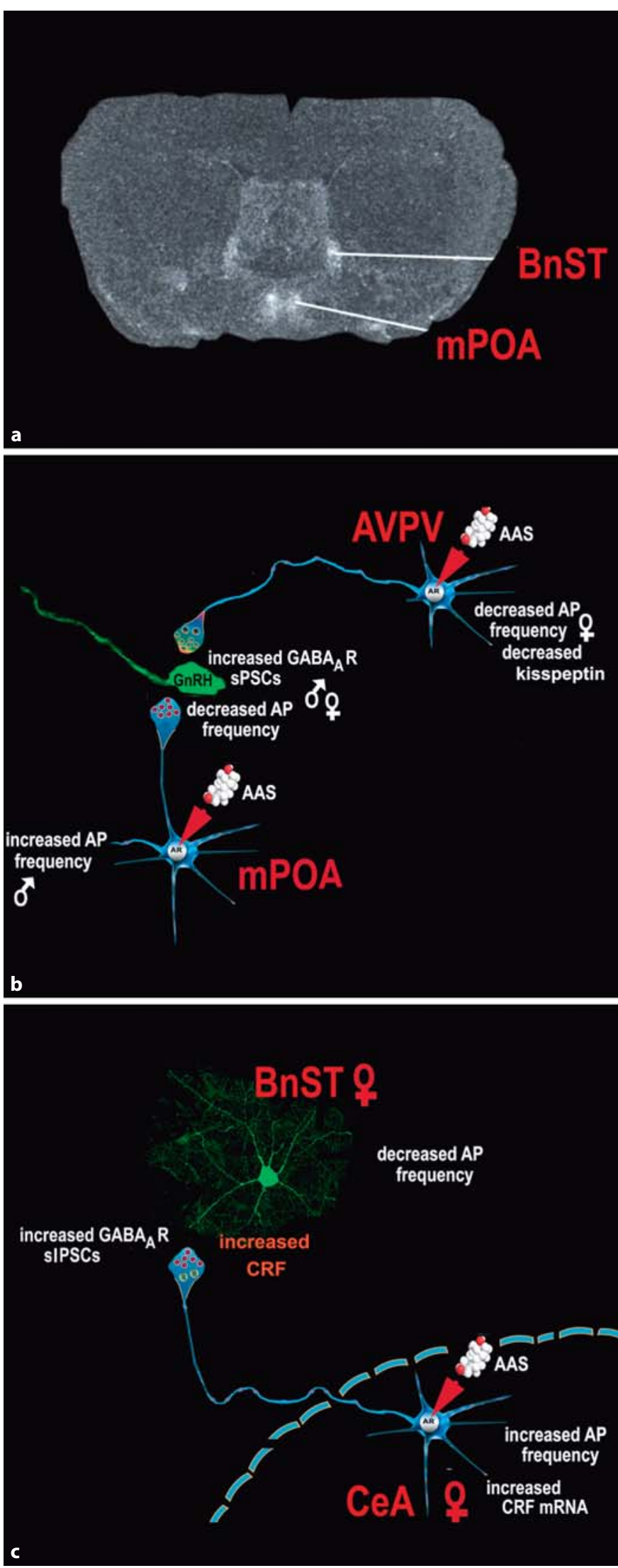
mentation of GABAergic inhibition in the BnST were dependent on corticotropin-releasing factor (CRF) signaling at the type 1 receptor $[75,77]$. While the direct role of AR, ER, or other nuclear hormone signaling pathways was not tested in this study, acute exposure to this AAS mixture did not elicit anxiogenic behaviors. Moreover, acute exposure to the steroid mixture had only postsynaptic (allosteric) effects on $\mathrm{GABA}_{\mathrm{A}}$ receptor-mediated sIPSC amplitudes (no effect on frequency) [75]. These data suggest that AAS actions through nuclear hormone signaling pathways are likely necessary to mediate the effects on GABAergic transmission at the CeA to BnST synapse (fig. 1c). It is also interesting to note that the actions of AAS in promoting a CRF-dependent increase in the release of GABA onto BnST neurons are highly reminiscent of the effects of chronic ethanol exposure on GABAergic afferents to the CeA neurons themselves [78-80]. Data determining the actions of ethanol on GABAergic transmission in these neurons highlight intriguing molecular avenues, such as the role of nociceptin/orphanin FQ [81], which should be explored with regard to mechanisms by which the AAS may lead not only to augmented GABA release, but also possibly changes in glutamatergic transmission in the extended amygdala [82].

In addition to augmenting presynaptic release of GABA via this CRF-dependent mechanism, recent studies have also illuminated a separate critical mechanism by which chronic AAS treatment may alter GABAergic transmission in neural circuits important in fear, anxiety, and depression. Specifically, it has been shown that chronic exposure to even relatively low doses of AAS inhibits the production of $5 \alpha$-reductase type I, and thus, the bioavailability of pregnane steroids, such as allopregnanolone, via an AR-mediated mechanism [26, 83-85]. While the electrophysiological correlates of AAS-mediated decreases in the concentrations of positive neurosteroid modulators were not examined in these studies, the most straightforward expectation would be for diminished GABAergic inhibition within neural circuits that express appreciable levels of $5 \alpha$-reductase type I and are implicated in the expression of fear and anxiety. Such expectations are consistent with data indicating that both increased anxiety [76] and contextual fear conditioning [86] involve decreases in GABAergic inhibition and disinhibition of key neural elements in these circuits.

Although AAS treatment of adult female mice was found to decrease the level of $5 \alpha$-reductase mRNA expression in glutamatergic neurons of the basolateral amygdala by $70 \%$, no changes were observed in the levels of mRNA for this enzyme in neurons of the central amygdala. Moreover, AAS treatment did not alter the levels of the transcript for this enzyme in GABAergic output neurons of the thalamus [85]. Such region- and cell-specific effects of AAS treatment are consistent with the observation that AAS treatment did not lead to significant changes in the time course of $\mathrm{GABA}_{\mathrm{A}}$ receptor-mediated postsynaptic current decay in BnST neurons [75], a result that may reflect low levels of expression of $5 \alpha$-reductase in the CeA projection neurons, and thus a lack of significant AAS-induced effect on neurosteroid modulation of postsynaptic GABAergic currents in the BnST.

An intriguing corollary to emerge from studies of the effect of the AAS on ion channels in the CNS is the observation that both social isolation [84] and chronic AAS exposure $[27,69]$ increase the expression of the $\alpha_{5}$-subunit of the $\mathrm{GABA}_{\mathrm{A}}$ receptor in regions of the forebrain involved in the production of anxiety and aggression [87] (including the mPOA $[27,69,88]$, the amygdala [88], the hippocampus [84], and the frontal cortex $[84,89])$, and enhance aggression and anxiety like-behaviors [26, 75, $77,90]$. As GABAergic transmission mediated by $\alpha_{5}$-containing receptors has been shown to be important in trace fear conditioning [91-93] and $\alpha_{5}$ expression is altered in high-anxiety versus normal lines of mice [94], these data suggest that changes in forebrain neurotransmission mediated by $\alpha_{5}$-containing receptors could play a significant role in AAS-induced fear, aggression, and anxiety.

It is also interesting to speculate that potential actions of the AAS, especially as they relate to fear and anxiety, may involve effects on GABAergic transmission that arise due to changes in the expression of neurotrophins and/or their receptors. Chronic treatment of adult male rats with either nandrolone decanoate or stanozolol was shown to result in significantly lower levels of brain-derived neurotrophic factor (BDNF) in the hippocampus and prefrontal cortex and to increase depression-like behavior $[95,96]$. BDNF can act to inhibit GABA receptormediated transmission [97] and may cause rapid sequestration of $\mathrm{GABA}_{\mathrm{A}}$ receptors in cultures of hippocampal or amygdalar neurons [98]. In addition, repeated cocaine exposure has been shown to result in elevated levels of BDNF in medial prefrontal cortex, which in turn, leads to enhanced long-term potentiation by reducing surface expression of $\mathrm{GABA}_{\mathrm{A}}$ receptors and GABAergic inhibition [99]. Thus, chronic abuse of AAS may also alter the balance of inhibition and excitation in CNS circuits that underlie anxiety and aggression by altering the levels of $\mathrm{BDNF}$ or other neurotrophins that promote sequestration of $\mathrm{GABA}_{\mathrm{A}}$ receptors in these cells. 
Finally, it is of great interest to consider the interplay between the actions of the AAS on CRF-mediated increases in inhibition observed in the BnST $[75,77]$ and extrapolate these data in thinking about a potential role for CRF as being a key player in imposing AAS-dependent changes in GABAergic transmission to GnRH neurons. The ability of stress, and in particular CRF, to alter the onset of puberty and suppress reproductive function is a cornerstone of the interactions between the hypothalamic/pituitary/gonadal and the hypothalamic/pituitary/ adrenal axes [100-102]. Moreover, as discussed in the companion article by Cunningham et al. [103] in the current issue, the $\mathrm{AR}$ has a key role in the reciprocal regulation of the HPA and HPG axes, thus underscoring the potential for AAS to influence this dynamic. Consistent with the known physiological actions of CRF and GABA on the control of reproduction, CRF mRNA is highly expressed within neurons of the mPOA [104, 105], and stress augments the activity of GABAergic neurons in this region [106]. CRF-containing terminals make direct contacts with GnRH neurons [104], and CRF receptor type 1 is expressed in these cells [107]. It is intriguing to speculate that AAS-dependent changes in CRF modulation of GABAergic transmission that are comparable to those observed in the BnST may also occur in the mPOA, and that this CRF-dependent modulation plays a pivotal role in the observed changes in the activity of MPOA [61] and AVPV [62] neurons that contribute to AAS suppression of the activity of GnRH neurons and to the negative effects of these steroids on reproductive competence.

\section{Voltage-Gated Ion Channels}

To date, no studies have assessed a direct action of the AAS, either allosteric or genomic, on the function of voltage-gated ion channels within the CNS. However, a handful of pivotal studies on peripheral tissue have demonstrated that AAS can also alter the function of these fundamental molecules of electrical excitability. Chronic exposure to $17 \alpha-\mathrm{MeT}$ was reported to cause broadening of the electric organ discharge (EOD) [108]. The EOD is a signal that is crucial for navigation, prey capture, and species-specific communication in weakly electric teleost fish which reflects the activity of single electrocytes (modified skeletal muscle-derived cells), as well as pacemaker neurons and their neuronal targets [109]. The basis for the broadening of the waveform has been attributed to an AR-mediated slowing of the rate of inactivation of voltage-dependent sodium channels and concomitant slowing of voltage-dependent potassium channel activation $[110,111]$. Chronic AAS treatment has also been shown to alter the current densities and kinetics of potassium currents [112] and autonomic control of contractility [113] in cardiac muscle and intracellular calcium homeostasis and the voltage-dependence of potassium contractures in skeletal muscle [114, 115]. Finally, chronic AAS treatment has been indirectly shown to alter electrical activity in the CNS as demonstrated by increased staining for the immediate early gene, c-FOS [116-118]. However, whether AAS-dependent modulation of Fos reflects changes in synaptic inputs or voltagegated conductances and the molecular identity of the channels altered remains to be determined.

\section{Future Directions}

At the protein and mRNA levels, chronic AAS exposure has been shown to impart significant effects on the expression or posttranslational modification of a host of critical neuronal signaling components, including NMDA receptors [119], serotonin receptors [120-124], and dopamine receptors [125-128]. However, no studies to date have explored the electrophysiological consequences of alterations in these receptors as a result of AAS exposure. Similarly, while chronic AAS treatment has been shown to alter sodium and potassium channel function in electrically excitable tissue in the periphery, as noted above no study to date has examined the effects of AAS on the expression and/or function of voltage-gated channels in the CNS. Given the broad range of actions that endogenous androgens have on ion channel function in electrically excitable tissue [33], it is likely that these synthetic steroids also alter neuronal function via effects on voltage-gated channels and intracellular ion homeostasis in the CNS. Assessment of how AAS modify expression of these other receptors and channels and how they influence their function via phosphorylation [96, 129] or direct allosteric modulation remain critical questions that need to be addressed to fully understand the neural and behavioral consequences of both licit and illicit use of AAS.

\section{Acknowledgements}

We thank Ms. Marie Onakomaiya for critical review of the manuscript. The authors' work was supported by the National Institutes of Health (DA022716 to LPH, DA014137 to LPH and training grant DK07508 to JGO). 


\section{References}

$>1$ Basaria S, Wahlstrom JT, Dobs AS: Clinical review 138: Anabolic-androgenic steroid therapy in the treatment of chronic diseases. J Clin Endocrinol Metab 2001;86:5108-5117.

72 Shahidi NT: A review of the chemistry, biological action, and clinical applications of anabolic-androgenic steroids. Clin Ther 2001;23:1355-1390.

$\checkmark 3$ Woerdeman J, de Ronde W: Therapeutic effects of anabolic androgenic steroids on chronic diseases associated with muscle wasting. Expert Opin Investig Drugs 2011; 20:87-97.

4 Kochakian C, Yesalis C: Anabolic-androgenic steroids: a historical perspective and definition; in Yesalis CE (ed): Anabolic Steroids in Sport and Exercise. Champaign, $\mathrm{Hu}$ man Kinetics, 2000, pp 4-33.

5 Llewellyn L: Anabolics, ed 6, revised. Jupiter, Body of Science, 2007.

-6 Trenton AJ, Currier GW: Behavioural manifestations of anabolic steroid use. CNS Drugs 2005;19:571-595.

$>7$ Kanayama G, Hudson JI, Pope HG Jr: Longterm psychiatric and medical consequences of anabolic-androgenic steroid abuse: a looming public health concern? Drug Alcohol Depend 2008;98:1-12.

8 Wu FC: Endocrine aspects of anabolic steroids. 1997;43:1289-1292.

$>9$ Daly RC, Su TP, Schmidt PJ, Pickar D, Murphy DL, Rubinow DR: Cerebrospinal fluid and behavioral changes after methyltestosterone administration: preliminary findings. Arch Gen Psychiatry 2001;58:172-177.

-10 Perry PJ, Kutscher EC, Lund BC, Yates WR, Holman TL, Demers L: Measures of aggression and mood changes in male weightlifters with and without androgenic anabolic steroid use. J Forensic Sci 2003;48:646-651.

11 Matsumoto AM, Bremner WJ: Serum testosterone assays - accuracy matters. J Clin Endocrinol Metab 2004;89:520-524.

12 Franke WW, Berendonk B: Hormonal doping and androgenization of athletes: a secret program of the German Democratic Republic government. Clin Chem 1997;43:12621279.

13 Gallaway S: The Steroid Bible, ed 3, revised. Honolulu, Belle International, 1997.

14 Singer N, Schmidt MS: Supplements for athletes draw alert from FDA. The New York Times, July 29, 2009, p B1.

15 Winters SJ: Androgens: endocrine physiology and pharmacology. NIDA Res Monogr 1990;102:113-130.

-16 Martini L, Melcangi RC, Maggi R: Androgen and progesterone metabolism in the central and peripheral nervous system. J Steroid Biochem Mol Biol 1993;47:195-205.

17 Ryan KJ: Biological aromatization of steroids. J Biol Chem 1959;234:268-272.

18 Quincey RV, Gray CH: The metabolism of $\left[{ }^{1,2-3} \mathrm{H}\right] 17-\alpha$-methyltestosterone in human subjects. J Endocrinol 1967;37:37-55.
19 Papaconstantinou AD, Umbreit TH, Goering PL, Brown KM: Effects of $17 \alpha$-methyltestosterone on uterine morphology and heat shock protein expression are mediated through estrogen and androgen receptors. J Steroid Biochem Mol Biol 2002;82:305-314.

20 de Gooyer ME, Oppers-Tiemissen HM, Leysen D, Verheul HA, Kloosterboer HJ: Tibolone is not converted by human aromatase to $7 \alpha$-methyl-17 $\alpha$-ethynylestradiol $(7 \alpha$-MEE) analyses with sensitive bioassays for estrogens and androgens and with LC-MSMS. Steroids 2003;68:235-243.

21 Saartok T, Dahlberg E, Gustafsson JA: Relative binding affinity of anabolic-androgenic steroids: comparison of the binding to the androgen receptors in skeletal muscle and in prostate, as well as to sex hormone-binding globulin. Endocrinology 1984;114:21002106.

22 Roselli CE: The effect of anabolic-androgenic steroids on aromatase activity and androgen receptor binding in the rat preoptic area. Brain Res 1998;792:271-276.

23 Fragkaki AG, Angelis YS, Koupparis M, Tsantili-Kakoulidou A, Kokotos G, Georgakopoulos C: Structural characteristics of anabolic androgenic steroids contributing to binding to the androgen receptor and to their anabolic and androgenic activities. Applied modifications in the steroidal structure. Steroids 2009;74:172-197.

24 Attardi BJ, Page ST, Hild SA, Coss CC, Matsumoto AM: Mechanism of action of bolandiol (19-nortestosterone-3 $\beta, 17 \beta$-diol), a unique anabolic steroid with androgenic, estrogenic, and progestational activities. J Steroid Biochem Mol Biol 2010;118:151-161.

25 Whitney AC, Clark AS: Effects of acute stanozolol treatment on puberty in female rats. Biol Reprod 2001;64:1460-1465.

26 Pinna G, Costa E, Guidotti A: Changes in brain testosterone and allopregnanolone biosynthesis elicit aggressive behavior. Proc Natl Acad Sci USA 2005;102:2135-2140.

$\checkmark 27$ Penatti CA, Porter DM, Henderson LP: Chronic exposure to anabolic androgenic steroids alters neuronal function in the mammalian forebrain via androgen receptor- and estrogen receptor-mediated mechanisms. J Neurosci 2009;29:12484-12496.

28 Kurling-Kailanto S, Kankaanpää A, Hautaniemi J, Seppälä T: Blockade of androgen or estrogen receptors reduces nandrolone's ability to modulate acute reward-related neurochemical effects of amphetamine in rat brain. Pharmacol Biochem Behav 2010;95: 422-427.

29 Attardi BJ, Hild SA, Reel JR: Dimethandrolone undecanoate: a new potent orally active androgen with progestational activity. Endocrinology 2006;147:3016-3026.
30 Luzárdo OP, Machín RP, Díaz-Chico BN, Fernandez L: Photoaffinity labeling identification of a specific binding protein for the anabolic steroids stanozolol and danazol: an oligomeric protein regulated by age, pituitary hormones, and ethinyl estradiol. Endocrinology 2000;141:3377-3387.

31 Mor G, Eliza M, Song J, Wiita B, Chen S, Naftolin F: $17 \alpha$-methyl testosterone is a competitive inhibitor of aromatase activity in Jar choriocarcinoma cells and macrophage-like THP-1 cells in culture. J Steroid Biochem Mol Biol 2001;79:239-246.

32 Zhang W, Zhang Y, Zhang L, Zhao H, Li X, Huang H, Lin H: The mRNA expression of $\mathrm{P}_{450}$ aromatase, gonadotropin $\beta$-subunits and FTZ-F1 in the orange-spotted grouper (Epinephelus coioides) during $17 \alpha$-methyltestosterone-induced precocious sex change. Mol Reprod Dev 2007;74:665-673.

33 Penatti CAA, Henderson LP: Androgen actions on receptors and channels: regulation of electrical excitability and synaptic transmission; in Pfaff DW, Etgen A, Fahrbach S, Rubin R (eds): Hormones, Brain and Behavior. Amsterdam, Elsevier, 2009, pp 12451274.

34 Handelsman DJ: Commentary: androgens and "anabolic steroids": the one-headed janus. Endocrinology 2011;152:1752-1754.

35 Henderson LP, Jorge J: Steroid modulation of $\mathrm{GABA}_{\mathrm{A}}$ receptors: from molecular mechanisms to CNS roles in reproduction, dysfunction and drug abuse; in Maue R (ed): Advances in Molecular and Cell Biology. 2004, pp 217-249.

36 Clark A, Jones B, Yang P, Henderson L: Anabolic androgenic steroids and the brain: novel actions at the $\mathrm{GABA}_{\mathrm{A}}$ receptor and on $\mathrm{GABA}_{\mathrm{A}}$ receptor mediated-behaviors; in Smith S (ed): Neurosteroid Effects in the Central Nervous System: The Role of the $\mathrm{GABA}_{\mathrm{A}}$ Receptor. Boca Raton, CRC Press LLC, 2004, pp 119-141.

-37 Henderson LP: Steroid modulation of GAB$\mathrm{A}_{\mathrm{A}}$ receptor-mediated transmission in the hypothalamus: effects on reproductive function. Neuropharmacology 2007;52:14391453.

38 Bitran D, Hilvers RJ, Frye CA, Erskine MS: Chronic anabolic-androgenic steroid treatment affects brain $\mathrm{GABA}_{\mathrm{A}}$ receptor-gated chloride ion transport. Life Sci 1996;58:573583.

39 Bitran D, Kellogg CK, Hilvers RJ: Treatment with an anabolic-androgenic steroid affects anxiety-related behavior and alters the sensitivity of cortical $\mathrm{GABA}_{\mathrm{A}}$ receptors in the rat. Horm Behav 1993;27:568-583.

40 Gunn BG, Brown AR, Lambert JJ, Belelli D: Neurosteroids and $\mathrm{GABA}_{\mathrm{A}}$ receptor interactions: a focus on stress. Front Neurosci 2011; 5:131. 
-41 Masonis AE, McCarthy MP: Direct effects of the anabolic/androgenic steroids, stanozolol and $17 \alpha$-methyltestosterone, on benzodiazepine binding to the $\gamma$-aminobutyric $\operatorname{acid}_{\mathrm{A}}$ receptor. Neurosci Lett 1995;189:35-38.

-42 Masonis AE, McCarthy MP: Effects of the androgenic/anabolic steroid stanozolol on $\mathrm{GABA}_{\mathrm{A}}$ receptor function: GABA-stimulated ${ }^{36} \mathrm{Cl}$ - influx and $\left[{ }^{35} \mathrm{~S}\right]$ TBPS binding. $\mathrm{J}$ Pharmacol Exp Ther 1996;279:186-193.

43 Yang P, Jones BL, Henderson LP: Mechanisms of anabolic androgenic steroid modulation of $\alpha_{1} \beta_{3} \gamma_{2 L} G_{B B A}$ receptors. Neuropharmacology 2002;43:619-633.

-44 Yang P, Jones BL, Henderson LP: Role of the $\alpha$ subunit in the modulation of $\mathrm{GABA}_{\mathrm{A}}$ receptors by anabolic androgenic steroids. Neuropharmacology 2005;49:300-316.

-45 Jones BL, Whiting PJ, Henderson LP: Mechanisms of anabolic androgenic steroid inhibition of mammalian $\varepsilon$-subunit-containing $\mathrm{GABA}_{\mathrm{A}}$ receptors. J Physiol 2006;573:571593.

-46 Belelli D, Herd MB, Mitchell EA, Peden DR, Vardy AW, Gentet L, Lambert JJ: Neuroactive steroids and inhibitory neurotransmission: mechanisms of action and physiological relevance. Neuroscience 2006;138:821829.

47 Jones MV, Westbrook GL: The impact of receptor desensitization on fast synaptic transmission. Trends Neurosci 1996;19:96-101.

48 Vicini S: THDOC and the $\mathrm{GABA}_{\mathrm{A}}$ receptor; in Smith S (ed): Neurosteroid Effects in the Central Nervous System: The Role of the $\mathrm{GABA}_{\mathrm{A}}$ Receptor. Boca Raton, CRC Press LLC, 2004, pp 63-75.

-49 Zheleznova NN, Sedelnikova A, Weiss DS: Function and modulation of $\delta$-containing $\mathrm{GABA}_{\mathrm{A}}$ receptors. Psychoneuroendocrinology 2009;34(suppl 1):S67-S73.

-50 Jones BL, Henderson LP: Trafficking and potential assembly patterns of $\varepsilon$-containing $\mathrm{GABA}_{\mathrm{A}}$ receptors. J Neurochem 2007;103: $1258-1271$.

-51 Lambert JJ, Belelli D, Hill-Venning C, Peters JA: Neurosteroids and $\mathrm{GABA}_{\mathrm{A}}$ receptor function. Trends Pharmacol Sci 1995; 16: 295-303.

52 Clark AS, Henderson LP: Behavioral and physiological responses to anabolic-androgenic steroids. Neurosci Biobehav Rev 2003; 27:413-436.

-53 Clark AS, Costine BA, Jones BL, KeltonRehkopf MC, Meerts SH, Nutbrown-Greene LL, Penatti CA, Porter DM, Yang P, Henderson LP: Sex- and age-specific effects of anabolic androgenic steroids on reproductive behaviors and on GABAergic transmission in neuroendocrine control regions. Brain Res 2006;1126:122-138.

- 54 Ojeda SR, Dubay C, Lomniczi A, Kaidar G, Matagne V, Sandau US, Dissen GA: Gene networks and the neuroendocrine regulation of puberty. Mol Cell Endocrinol 2010; 324:3-11.
5 Semaan SJ, Kauffman AS: Sexual differentiation and development of forebrain reproductive circuits. Curr Opin Neurobiol 2010;20: 424-431.

56 Herbison AE, Moenter SM: Depolarising and hyperpolarising actions of $\mathrm{GABA}_{\mathrm{A}}$ receptor activation on gonadotrophin-releasing hormone neurones: towards an emerging consensus. J Neuroendocrinol 2011;23:557-569.

-57 Irving LM, Wall M, Neumark-Sztainer D, Story M: Steroid use among adolescents: findings from Project EAT. J Adolesc Health 2002;30:243-252.

58 Johnston L, O'Malley P, Bachman J, Schulenberg J: Monitoring the Future National Results on Adolescent Drug Use: Overview of Key Findings, 2008. Bethesda, National Institute on Drug Abuse, 2009, p 73.

59 Sato SM, Schulz KM, Sisk CL, Wood RI: Adolescents and androgens, receptors and rewards. Horm Behav 2008;53:647-658.

-60 Schulz KM, Zehr JL, Salas-Ramirez KY, Sisk CL: Testosterone programs adult social behavior before and during, but not after, adolescence. Endocrinology 2009; 150:36903698.

61 Penatti CA, Davis MC, Porter DM, Henderson LP: Altered $\mathrm{GABA}_{\mathrm{A}}$ receptor-mediated synaptic transmission disrupts the firing of gonadotropin-releasing hormone neurons in male mice under conditions that mimic steroid abuse. J Neurosci 2010;30:6497-6506.

62 Penatti CA, Oberlander JG, Davis MC, Porter DM, Henderson LP: Chronic exposure to anabolic androgenic steroids alters activity and synaptic function in neuroendocrine control regions of the female mouse. Neuropharmacology 2011;61:653-664.

63 Simerly RB: Wired for reproduction: organization and development of sexually dimorphic circuits in the mammalian forebrain. Annu Rev Neurosci 2002;25:507-536.

64 Simerly RB, Chang C, Muramatsu M, Swanson LW: Distribution of androgen and estrogen receptor mRNA-containing cells in the rat brain: an in situ hybridization study. J Comp Neurol 1990;294:76-95.

65 Dakin CL, Wilson CA, Kallo I, Coen CW, Davies DC: Neonatal stimulation of $5-\mathrm{HT}_{2}$ receptors reduces androgen receptor expression in the rat anteroventral periventricular nucleus and sexually dimorphic preoptic area. Eur J Neurosci 2008;27:2473-2480.

66 Scott CJ, Tilbrook AJ, Rawson JA, Clarke IJ: Gonadal steroid receptors in the regulation of $\mathrm{GnRH}$ secretion in farm animals. Anim Reprod Sci 2000;60-61:313-326.

67 Grattan DR, Jasoni CL, Liu X, Anderson GM, Herbison AE: Prolactin regulation of gonadotropin-releasing hormone neurons to suppress luteinizing hormone secretion in mice. Endocrinology 2007; 148:4344-4351.

68 Herbison AE: Estrogen positive feedback to gonadotropin-releasing hormone $(\mathrm{GnRH})$ neurons in the rodent: the case for the rostral periventricular area of the third ventricle (RP3V). Brain Res Rev 2008;57:277-287.
69 Penatti CA, Costine BA, Porter DM, Henderson LP: Effects of chronic exposure to an anabolic androgenic steroid cocktail on $\alpha 5$-receptor-mediated GABAergic transmission and neural signaling in the forebrain of female mice. Neuroscience 2009;161:526-537.

70 Herbison AE: Estrogen regulation of GABA transmission in rat preoptic area. Brain Res Bull 1997;44:321-326.

71 Midgley SJ, Heather N, Davies JB: Levels of aggression among a group of anabolic-androgenic steroid users. Med Sci Law 2001;41: 309-314.

72 Gruber AJ, Pope HG Jr: Psychiatric and medical effects of anabolic-androgenic steroid use in women. Psychother Psychosom 2000; 69:19-26.

73 Pagonis TA, Angelopoulos NV, Koukoulis GN, Hadjichristodoulou CS: Psychiatric side effects induced by supraphysiological doses of combinations of anabolic steroids correlate to the severity of abuse. Eur Psychiatry 2006;21:551-562.

74 Malone DA Jr, Dimeff RJ, Lombardo JA, Sample RH: Psychiatric effects and psychoactive substance use in anabolic-androgenic steroid users. Clin J Sport Med 1995;5:25-31.

75 Oberlander JG, Henderson LP: Corticotropin releasing factor modulation of forebrain GABAergic transmission has a pivotal role in the expression of anabolic steroid-induced anxiety in the female mouse. Neuropsychopharmacology 2012;37:1483-1499.

76 Davis M, Walker DL, Miles L, Grillon C: Phasic vs sustained fear in rats and humans: role of the extended amygdala in fear vs anxiety. Neuropsychopharmacology 2010;35: 105-135.

77 Costine BA, Oberlander JG, Davis MC, Penatti CA, Porter DM, Leaton RN, Henderson LP: Chronic anabolic androgenic steroid exposure alters corticotropin releasing factor expression and anxiety-like behaviors in the female mouse. Psychoneuroendocrinology 2010;35:1473-1485.

78 Roberto M, Cruz MT, Gilpin NW, Sabino V, Schweitzer P, Bajo M, Cottone P, Madamba SG, Stouffer DG, Zorrilla EP, Koob GF, Siggins GR, Parsons LH: Corticotropin releasing factor-induced amygdala gamma-aminobutyric acid release plays a key role in alcohol dependence. Biol Psychiatry 2010;67: 831-839.

79 Roberto M, Madamba SG, Moore SD, Tallent MK, Siggins GR: Ethanol increases GABAergic transmission at both pre- and postsynaptic sites in rat central amygdala neurons. Proc Natl Acad Sci USA 2003;100:2053-2058.

- 80 Roberto M, Madamba SG, Stouffer DG, Parsons LH, Siggins GR: Increased GABA release in the central amygdala of ethanol-dependent rats. J Neurosci 2004;24:1015910166. 
-81 Cruz MT, Herman MA, Kallupi M, Roberto M: Nociceptin/orphanin FQ blockade of corticotropin-releasing factor-induced gamma-aminobutyric acid release in central amygdala is enhanced after chronic ethanol exposure. Biol Psychiatry 2012;71:666-676.

82 Conrad KL, Winder DG: Altered anxietylike behavior and long-term potentiation in the bed nucleus of the stria terminalis in adult mice exposed to chronic social isolation, unpredictable stress, and ethanol beginning in adolescence. Alcohol 2011;45: 585-593.

-83 Pibiri F, Nelson M, Guidotti A, Costa E, Pinna G: Decreased corticolimbic allopregnanolone expression during social isolation enhances contextual fear: a model relevant for posttraumatic stress disorder. Proc Natl Acad Sci USA 2008;105:5567-5572.

-84 Pinna G, Agis-Balboa RC, Zhubi A, Matsumoto K, Grayson DR, Costa E, Guidotti A: Imidazenil and diazepam increase locomotor activity in mice exposed to protracted social isolation. Proc Natl Acad Sci USA 2006; 103:4275-4280.

-85 Agis-Balboa RC, Pibiri F, Nelson M, Pinna G: Enhanced fear responses in mice treated with anabolic androgenic steroids. Neuroreport 2009;20:617-621.

86 Lin HC, Mao SC, Gean PW: Block of $\gamma$-aminobutyric acid-A receptor insertion in the amygdala impairs extinction of conditioned fear. Biol Psychiatry 2009;66:665-673.

87 Oberlander JG, Henderson LP: The sturm und drang of anabolic steroid use: angst, anxiety, and aggression. Trends Neurosci 2012, E-pub ahead of print.

- 88 McIntyre KL, Porter DM, Henderson LP: Anabolic androgenic steroids induce age-, sex-, and dose-dependent changes in GAB$\mathrm{A}_{\mathrm{A}}$ receptor subunit mRNAs in the mouse forebrain. Neuropharmacology 2002; 43: 634-645.

89 Pibiri F, Nelson M, Carboni G, Pinna G: Neurosteroids regulate mouse aggression induced by anabolic androgenic steroids. Neuroreport 2006;17:1537-1541.

90 Robinson S, Penatti CA, Clark AS: The role of the androgen receptor in anabolic androgenic steroid-induced aggressive behavior in C57BL/6J and Tfm mice. Horm Behav 2012; 61:67-75.

-91 Crestani F, Keist R, Fritschy JM, Benke D, Vogt K, Prut L, Bluthmann H, Möhler H, Rudolph U: Trace fear conditioning involves hippocampal $\alpha_{5} \mathrm{GABA}_{\mathrm{A}}$ receptors. Proc Natl Acad Sci USA 2002;99:8980-8985.

-92 Yee BK, Keist R, von Boehmer L, Studer R, Benke D, Hagenbuch N, Dong Y, Malenka RC, Fritschy JM, Bluethmann H, Feldon J, Möhler H, Rudolph U: A schizophrenia-related sensorimotor deficit links $\alpha 3$-containing $\mathrm{GABA}_{\mathrm{A}}$ receptors to a dopamine hyperfunction. Proc Natl Acad Sci USA 2005;102: 17154-17159.
$\$ 93$ Heldt SA, Ressler KJ: Training-induced changes in the expression of $\mathrm{GABA}_{\mathrm{A}}$-associated genes in the amygdala after the acquisition and extinction of Pavlovian fear. Eur J Neurosci 2007;26:3631-3644.

$\$ 94$ Tasan RO, Bukovac A, Peterschmitt YN, Sartori SB, Landgraf R, Singewald N, Sperk G: Altered GABA transmission in a mouse model of increased trait anxiety. Neuroscience 2011;183:71-80.

95 Matrisciano F, Modafferi AM, Togna GI, Barone Y, Pinna G, Nicoletti F, Scaccianoce S: Repeated anabolic androgenic steroid treatment causes antidepressant-reversible alterations of the hypothalamic-pituitaryadrenal axis, BDNF levels and behavior. Neuropharmacology 2010;58:1078-1084.

96 Rossbach UL, Steensland P, Nyberg F, Le Grevès P: Nandrolone-induced hippocampal phosphorylation of NMDA receptor subunits and ERKs. Biochem Biophys Res Commun 2007;357:1028-1033.

-97 Tanaka T, Saito H, Matsuki N: Inhibition of $\mathrm{GABA}_{\mathrm{A}}$ synaptic responses by brain-derived neurotrophic factor (BDNF) in rat hippocampus. J Neurosci 1997;17:2959-2966.

$\checkmark 98$ Mou L, Heldt SA, Ressler KJ: Rapid brainderived neurotrophic factor-dependent sequestration of amygdala and hippocampal $\mathrm{GABA}_{\mathrm{A}}$ receptors via different tyrosine receptor kinase B-mediated phosphorylation pathways. Neuroscience 2011;176:72-85.

$\$ 99 \mathrm{Lu} \mathrm{H}$, Cheng PL, Lim BK, Khoshnevisrad N, Poo MM: Elevated BDNF after cocaine withdrawal facilitates LTP in medial prefrontal cortex by suppressing GABA inhibition. Neuron 2010;67:821-833.

100 Chand D, Lovejoy DA: Stress and reproduction: controversies and challenges. Gen Comp Endocrinol 2011;171:253-257.

101 Veldhuis JD, Keenan DM, Pincus SM: Regulation of complex pulsatile and rhythmic neuroendocrine systems: the male gonadal axis as a prototype. Prog Brain Res 2010; 181:79-110.

102 Li XF, Knox AMI, O’Byrne KT: Corticotropin-releasing factor and stress-induced inhibition of the gonadotropin-releasing hormone pulse generator in the female. Brain Res 2010;1364:153-163.

103 Cunningham RL, Lumia AR, McGinnis MY: Androgen receptors, sex behavior, and aggression. Neuroendocrinology 2012;96: 131-140.

104 MacLusky NJ, Naftolin F, Leranth C: Immunocytochemical evidence for direct synaptic connections between corticotrophinreleasing factor (CRF) and gonadotrophinreleasing hormone $(\mathrm{GnRH})$-containing neurons in the preoptic area of the rat. Brain Res 1988;439:391-395.

105 Keegan CE, Herman JP, Karolyi IJ, O’Shea KS, Camper SA, Seasholtz AF: Differential expression of corticotropin-releasing hormone in developing mouse embryos and adult brain. Endocrinology 1994;134:25472555.
106 Lin YS, Li XF, Shao B, Hu MH, Goundry AL, Jeyaram A, Lightman SL, O'Byrne KT: The role of GABAergic signalling in stressinduced suppression of GnRH pulse generator frequency in female rats. J Neuroendocrinol 2012;24:477-488.

107 Jasoni CL, Todman MG, Han SK, Herbison $\mathrm{AE}$ : Expression of mRNAs encoding receptors that mediate stress signals in gonadotropin-releasing hormone neurons of the mouse. Neuroendocrinology 2005;82:320328.

108 Bass AH, Volman SF: From behavior to membranes: testosterone-induced changes in action potential duration in electric organs. Proc Natl Acad Sci USA 1987;84: 9295-9298.

109 Bass AH, Zakon HH: Sonic and electric fish: at the crossroads of neuroethology and behavioral neuroendocrinology. Horm Behav 2005;48:360-372.

110 Ferrari MB, McAnelly ML, Zakon HH: Individual variation in and androgen-modulation of the sodium current in electric organ. J Neurosci 1995;15:4023-4032.

111 McAnelly ML, Zakon HH: Androgen modulates the kinetics of the delayed rectifying $\mathrm{K}^{+}$current in the electric organ of a weakly electric fish. Dev Neurobiol 2007;67:15891597.

112 Medei E, Marocolo M, Rodrigues de Carvalho Rodrigues, Arantes PC, Takiya CM, Silva J, Rondinelli E, Goldenberg RC, de Carvalho AC, Nascimento JH: Chronic treatment with anabolic steroids induces ventricular repolarization disturbances: cellular, ionic and molecular mechanism. J Mol Cell Cardiol 2010;49:165-175.

113 Pereira-Junior PP, Chaves EA, Costa ESRH, Masuda MO, De Carvalho AC, Nascimento $\mathrm{JH}$ : Cardiac autonomic dysfunction in rats chronically treated with anabolic steroid. Eur J Appl Physiol 2006;96:487-494.

114 Bouhlel A, Joumaa WH, Léoty C: Nandrolone decanoate reduces changes induced by hindlimb suspension in voltage-dependent tension of rat soleus muscle. Jpn J Physiol 2003;53:77-87.

115 Bouhlel A, Joumaa WH, Léoty C: Nandrolone decanoate treatment affects sarcoplasmic reticulum $\mathrm{Ca}^{2+}$ ATPase function in skinned rat slow- and fast-twitch fibres. Pflugers Arch 2003;446:728-734.

116 Johansson-Steensland P, Nyberg F, Chahl $\mathrm{L}$ : The anabolic androgenic steroid, nandrolone decanoate, increases the density of Fos-like immunoreactive neurons in limbic regions of guinea-pig brain. Eur J Neurosci 2002; 15:539-544.

117 Tamaki T, Shiraishi T, Takeda H, Matsumiya T, Roy RR, Edgerton VR: Nandrolone decanoate enhances hypothalamic biogenic amines in rats. Med Sci Sports Exerc 2003;35:32-38 
118 Carrillo M, Ricci LA, Melloni RH Jr: Adolescent anabolic androgenic steroids reorganize the glutamatergic neural circuitry in the hypothalamus. Brain Res 2009;1249: 118-127.

119 Le Grevès P, Huang W, Johansson P, Thornwall M, Zhou Q, Nyberg F: Effects of an anabolic-androgenic steroid on the regulation of the NMDA receptor NR1, NR2A and NR2B subunit mRNAs in brain regions of the male rat. Neurosci Lett 1997;226:61-64.

120 Kindlundh AM, Lindblom J, Bergström L, Nyberg F: The anabolic-androgenic steroid nandrolone induces alterations in the density of serotonergic $5 \mathrm{HT}_{1 \mathrm{~B}}$ and $5 \mathrm{HT}_{2}$ receptors in the male rat brain. Neuroscience 2003;119:113-120.

121 Grimes JM, Melloni RH Jr: Serotonin-1B receptor activity and expression modulate the aggression-stimulating effects of adolescent anabolic steroid exposure in hamsters. Behav Neurosci 2005;119:1184-1194.
122 Grimes JM, Melloni RH Jr: Prolonged alterations in the serotonin neural system following the cessation of adolescent anabolic-androgenic steroid exposure in hamsters (Mesocricetus auratus). Behav Neurosci 2006;120:1242-1251

123 Ambar G, Chiavegatto S: Anabolic-androgenic steroid treatment induces behavioral disinhibition and downregulation of serotonin receptor messenger RNA in the prefrontal cortex and amygdala of male mice. Genes Brain Behav 2009;8:161-173.

124 Schwartzer JJ, Ricci LA, Melloni RH Jr: Adolescent anabolic-androgenic steroid exposure alters lateral anterior hypothalamic serotonin-2A receptors in aggressive male hamsters. Behav Brain Res 2009;199:257262.

125 Kindlundh AM, Lindblom J, Bergström L, Wikberg JE, Nyberg F: The anabolic-androgenic steroid nandrolone decanoate affects the density of dopamine receptors in the male rat brain. Eur J Neurosci 2001;13: 291-296.
26 Ricci LA, Schwartzer JJ, Melloni RH Jr: Alterations in the anterior hypothalamic dopamine system in aggressive adolescent AAS-treated hamsters. Horm Behav 2009; 55:348-355.

127 Schwartzer JJ, Melloni RH Jr: Anterior hypothalamic dopamine D2 receptors modulate adolescent anabolic/androgenic steroid-induced offensive aggression in the Syrian hamster. Behav Pharmacol 2010;21: 314-322.

128 Schwartzer JJ, Melloni RH Jr: Dopamine activity in the lateral anterior hypothalamus modulates AAS-induced aggression through D2 but not D5 receptors. Behav Neurosci 2010;124:645-655.

129 Rossbach UL, Le Grevès M, Nyberg F, Zhou $\mathrm{Q}$, Le Grevès P: Acute 19-nortestosterone transiently suppresses hippocampal MAPK pathway and the phosphorylation of the NMDA receptor. Mol Cell Endocrinol 2010; 314:143-149. 